\title{
The Usefulness as a Specific Marker of Blood and Nasal Lavage Fluid YKL-40 in Allergic Rhinitis Patients
}

\author{
Do-Sim Park ${ }^{1}$, Young-Jin Lee ${ }^{1}$, Joon Lim², Sang-Woo Yoo ${ }^{2}$, Gi-Sung Nam² and Jae-Hoon Lee ${ }^{2}$ \\ ${ }^{1}$ Departments of Laboratory Medicine, ${ }^{2}$ Otolaryngology-Head \& Neck Surgery, Institute of Wonkwang Medical Science, \\ School of Medicine, Wonkwang University, Iksan, Korea
}

\section{알레르기비염 환자의 혈청 및 비세척액에서 $\mathrm{YKL}-40$ 의 특이 표지자로서의 유용성}

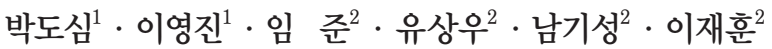

원광대학교 의과대학 진단검사의학교실, ${ }^{1}$ 이비인후과학교실 ${ }^{2}$

\author{
Received December 20, 2011 \\ Revised March 1, 2012 \\ Accepted March 3, 2012 \\ Address for correspondence \\ Jae-Hoon Lee, MD \\ Department of Otolaryngology- \\ Head \& Neck Surgery, \\ Institute of Wonkwang \\ Medical Science, \\ School of Medicine, \\ Wonkwang University, \\ 895 Muwang-ro, \\ Iksan 570-711, Korea \\ Tel $+82-63-859-1441$ \\ Fax $+82-63-841-6556$ \\ E-mail coolnose@wmc.wonkwang. \\ ac.kr
}

Background and Objectives Chitin is a recognition element for tissue infiltration by innate cells implicated in allergy and asthma. Chitinases are characterized by the ability to cleave chitin. YKL-40, the chitinase-like protein, was increased during Th2-type inflammation in an exaggerated manner in tissues of patients with asthma. However, the relationship of YKL-40 level to allergic rhinitis has not been evaluated. Hence, we evaluated the relationship between the YKL-40 level in the blood and nasal lavage fluid and allergic inflammation in nasal cavity. We also evaluated the nature of association between several important factors (eosinophil count and total $\mathrm{IgE}$ ) in the blood and nasal lavage fluid of allergic rhinitis patients. Subjects and Method The concentrations of the YKL-40 levels in the blood and nasal lavage fluid were compared between allergic rhinitis patients and healthy controls. We evaluated the YKL-40 levels in the blood and nasal lavage fluid and also evaluated symptom severity, eosinophil count, and total IgE.

Results The blood YKL-40 level was not significantly increased in allergic rhinitis (49 pg/ $\mathrm{mL})$ than in control $(44 \mathrm{pg} / \mathrm{mL})(p>0.05)$. The YKL-40 levels in the nasal lavage fluid was not significantly increased in allergic rhinitis $(1568 \mathrm{pg} / \mathrm{mL})$ than in control $(1248 \mathrm{pg} / \mathrm{mL})(p>0.05)$. The YKL-40 levels in blood and nasal lavage fluid were not associated with important factors such as symptom severity, eosinophil count, and total IgE in allergic rhinitis patients.

Conclusion There is no association between the YKL-40 level in the blood and nasal lavage fluid, allergic inflammation in nasal cavity.

Korean J Otorhinolaryngol-Head Neck Surg 2012;55:161-5

Key Words Allergic rhinitis · YKL-40 - Chitin - Chitinase.

\section{서 론}

알레르기비염은 특정항원에 노출된 이후 $\mathrm{IgE}$ 에 의해 매개된 과민성 면역반응에 의한 코의 염증반응으로 나타나는 질환으 로 국소적인 증상만을 보이는 경우도 있으나, 흔히 다른 알레르 기 질환과 동반되며 전신적 질환의 일부 발현으로 보기도 한 다. ${ }^{1,2)}$ 따라서 다른 알레르기 질환과 공통된 병태생리적 특징
을 갖는 것으로 여겨지고 있다.

Chitin[B-(1-4)-poly-N-acetyl D-glucosamine]은 자연에 서 cellulose 다음으로 가장 풍부한 polysaccharide이다. ${ }^{3-5)}$ 박 테리아, 곰팡이, 버섯의 세포벽, 게, 새우와 같은 갑각류 혹은 곤 충의 껍질, 많은 곤충들의 소화기에서 존재한다. ${ }^{3-5)}$ Chitin을 가지고 있는 생물체는 chitin이 기생충에 대한 방어역할, 병원 균의 면역반응에 작용하는 것으로 알려져 있다. 면역반응에서 
의 chitin은 제 1 형 면역반응을 증가시키고, 제 2 형 면역반응을 억제하는 것으로 알려져 있다.) Chitin을 코 안으로 주입하는 동 물실험에서 주입 후 알레르기 항원에 의한 혈청 $\operatorname{IgE}$, 호산구, 기 도과민반응, 폐 염증반응들을 감소시켰다.) 많은 포유동물들 은 chitin을 직접 생성하지는 않지만 chitin을 가지고 있는 병원 체에 방어역할로 chitin을 분해하는 효소들인 chitinases를 가 지고 있다.,9) Chitinases 중의 하나로 알려진 acidic mammalian chitinase(CHIA)가 천식의 제2형 면역반응과 관련됨이 보 고되었다.10) 특히 천식 환자의 연구에서 인간에 존재하는 chitinase인 YKL-40[human cartilage glycoprotein 39 혹은 chitinase 3-like 1(CHI3LI)이라고도 불림]의 혈청 및 기관폐포세 척액에서 증가되며, 천식의 심한 정도에 비례하는 것으로 밝혀 졌다. ${ }^{11}$ 현재까지 알레르기비염과 chitinase와의 연관성에 대한 연구는 미미한 상태로, 저자들은 알레르기비염 환자의 혈청과 비세척액(nasal lavage fluid)에서 YKL-40의 수준을 측정하 여 정상대조군과 비교하였으며, 알레르기비염 환자의 증상점 수에 따라 경증-중등군과 중증군, allergic rhinitis and its impact on asthma(ARIA) 분류에 따라 경증군과 중등-중증군으 로 구분하여 YKL-40의 수준을 서로 비교하였다.

\section{대상 및 방법}

\section{대 상}

재채기, 맑은 콧물, 코막힘을 주소로 본원 이비인후과를 방 문하여 알레르기비염으로 의심되는 환자 중, multiple allergen simultaneous test(MAST)에서 알레르기비염으로 판정된 성인 환자 62명[30 12 세(19 45세), 남: 35명, 여: 27명]을 대상으로 하였다. 알레르기 항원특이 IgE 항체는 Allergy Screen(R-Biopharm, Darmstadt, Germany)을 이용한 MAST로 측정하였 다. 화학발광도에 따라 class $0(0.00 \sim 0.34 \mathrm{IU} / \mathrm{mL})$, class $1(0.35$ $0.69 \mathrm{IU} / \mathrm{mL})$, class 2(0.70 3.49 IU/mL), class 3(3.50 17.49 IU/ $\mathrm{mL})$, class 4(17.50 49.99 IU/mL), class 5(50.00 99.99 IU/ $\mathrm{mL})$, class $6(\geq 100 \mathrm{IU} / \mathrm{mL})$ 로 구분하였다. 집먼지, 집먼지 진 드기, 곰팡이, 개, 고양이, 바퀴벌레, 꽃가루, 목초 등과 같은 총 39 종의 알레르기 항원에 대한 특이 $\mathrm{IgE}$ 농도를 측정하였고 class 2 이상인 경우 양성으로 판정하였다.

내원 4주 이내에 항히스타민제, 스테로이드 및 항생제를 사 용한 경우나 과거에 비과적 수술을 받은 경우는 제외하였고, 천식 및 아토피성 피부염 같은 알레르기질환이 동반된 경우 도 제외하였다. 대조군은 알레르기비염을 포함한 알레르기 질 환의 가족력 및 병력이 없고 MAST에서 음성을 보인 건강

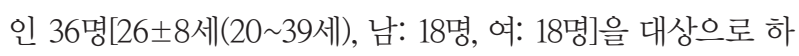
였다.
환자군은 설문지를 통해 코막힘, 콧물의 정도, 재채기 회수 에 대하여 각 증상을 0 3 단계로 점수화[0: 무증상, 1: 경증, 2: 중등, 3 : 중증(총점: 0-9)]하여 ${ }^{12}$ 증상 합산 점수에 따라 경 도-중등도(1-6), 중증도(7-9)의 두 군으로 분류하였다. 또한 설 문지를 통해 ARIA 분류 ${ }^{13}$ 를 시행하였다. 금번 연구는 병원 내 임상실험윤리위원회의 승인을 얻어 실시하였다.

\section{방 법}

혈중 호산구는 자동혈구계산기인 Sysmex 9000(Toa Medical Electronics, Kobe, Japan)으로 분석하고, 혈청 IgE는 Cobas Integra 800(Roche Diagnostics, Basel, Switzerland)으 로 분석하였다. 혈청 $\mathrm{IgE}$ 가 측정범위 $(<2000 \mathrm{U} / \mathrm{mL})$ 를 벗어나 는 경우는 희석하여 측정하였다. 비세척은 $0.9 \%$ 의 생리식염수 를 사용하였으며 피검자가 앉은 자세에서 먼저 비강내를 흡입 기로 간단히 청소한 후 한쪽 비강내에서 $5 \mathrm{~mL}$ 의 식염수로 10 초간 유지하여 배출 후 모아두었다. 비세척액 내에서 백혈구 중 호산구 비율을 측정하기 위해 비강세척액을 원심 분리(750 g 로 5 분)한 후 $50 \mu \mathrm{L}$ 를 취하여 cytospin으로 슬라이드를 제작 한 다음 Diff-Quik 염색액(Sysmex Co., Kobe, Japan)을 이용 하여 염색 후 관찰하였다. 나머지는 YKL-40 농도 측정을 위 해 $-70^{\circ} \mathrm{C}$ 에 보관하였다.

혈중 YKL-40은 상업화 된 ELISA kit(R \& D systems, Minneapolis, MN, USA)를 이용하여 제조사의 지침에 따라 측정 하였다. 환자 혈청은 500 배 인산화 완충액을 이용하여 희석 후 측정하였고, 측정범위보다 높거나 낮은 경우 50 배 및 5000 배 희석하여 검사하여 각 희석 배수를 곱하였고, 식염수 비강 세척액은 희석 없이 검사하고, 측정범위보다 높은 경우 50 배 희 석하여 검사하여 희석 배수를 곱하였다. Anti-human YKL-40 항체로 microwell을 코팅 후 세척액으로 4회 세척하였고, 300 $\mu \mathrm{L}$ blocking 완충액을 분주하여 2시간 방치 후 세척액으로 4 회 세척하였다. 희석된 환자 및 대조군 혈청과 비강세척액을 $100 \mu \mathrm{L}$ 씩 분주한 후 실온에 2시간 반응시키고 4회 세척하였 다. 이후 바이오틴이 결합된 anti-human YKL-40 항체를 100 $\mu \mathrm{L}$ 씩 주입한 후 2 시간 실온에 방치 후 4회 세척하였다. 스트 렙타비딘-퍼옥시다제 접합체를 $100 \mu \mathrm{L}$ 분주하고 20 분간 실 온에 방치하였다가 4 회 세척하였다. 이후 $100 \mu \mathrm{L}$ 의 효소 기질 액을 첨가하여 실온에 10 분간 반응 후 $100 \mu \mathrm{L}$ 의 정지액을 첨 가하고 $450 \mathrm{~nm}$ 에서 ELISA plate 판독기(Molecular Devices, Synnyvale, CA, USA)에 흡광도를 측정하고 표준곡선과 비교 하여 계산하였다.

\section{통 계}

전체 알레르기비염 환자군과 대조군 및 알레르기비염 환자 
군의 증상점수에 따른 경증-중등군과 중증군, $\mathrm{ARIA}$ 분류에 따른 경증군과 중등-중증군을 평균土표준오차로 나타내고, 평균비교는 Student's t-검정을 사용하였다. 유의성은 $p$ 값이 0.05 미만인 경우, 통계적으로 유의하다고 판정하였다.

\section{결 과}

\section{알레르기비염 환자군와 대조군에서 혈중 YKL-40}

(B-YKL)과 비세척액 $\mathrm{YKL}-40(\mathrm{NL}-\mathrm{YKL})$ 의 비교

$\mathrm{B}-\mathrm{YKL}$ 수준은 알레르기비염 환자군 $(49 \pm 7 \mathrm{pg} / \mathrm{mL})$ 과 대 조군 $(44 \pm 5 \mathrm{pg} / \mathrm{mL})$ 간에 유의한 차이가 없었다 $(p>0.05)$ (Fig. 1). NL-YKL 수준은 알레르기비염 환자군 $(1248 \pm 98 \mathrm{pg} / \mathrm{mL})$ 과 대조군 $(1568 \pm 119 \mathrm{pg} / \mathrm{mL})$ 간에 유의한 차이가 없었다 $(p>$ 0.05)(Fig. 1).
알레르기비염 증상점수에 따른 경증-중등군(1 6점)과

중증군(7 9점)과의 B-YKL와 $\mathrm{NL}-\mathrm{YKL}$ 비교와

알레르기 비염의 3대 증상(코막힘, 콧물, 재채기)의

점수에 대한 $\mathrm{B}-\mathrm{YKL}$ 과 $\mathrm{NL}-\mathrm{YKL}$ 과의 상관성

알레르기비염 증상 점수에 따른 분류에서 경증-중등군이 42 명, 중증군이 20 명이었다. 두군 간의 혈청 total $\mathrm{IgE}$ 의 비교 에서 중증군 $(747 \pm 218 \mathrm{U} / \mathrm{mL})$ 이 경증-중등군 $(433 \pm 65 \mathrm{U} / \mathrm{mL})$ 보다 증가되었으나 유의한 차이를 보이지 않았다 $(p>0.05)$. 두 군 간의 혈중 호산구 수의 비교에서 알레르기 환자의 중증군 $(310 \pm 50 / \mu \mathrm{L})$ 이 경증-중등군 $(240 \pm 20 / \mu \mathrm{L})$ 보다 증가되었으나 유의한 차이는 보이지 않았다 $(p>0.05)$.

$\mathrm{B}-\mathrm{YKL}$ 수준은 경증-중등군 $(46 \pm 7 \mathrm{pg} / \mathrm{mL})$ 과 중증군 $(81 \pm$ $20 \mathrm{pg} / \mathrm{mL}$ ) 간에 유의한 차이가 없었다 $(p>0.05)$ (Fig. 2). NL$\mathrm{YKL}$ 수준은 경증-중등군 $(1287 \pm 116 \mathrm{pg} / \mathrm{mL})$ 과 중증군(1113 \pm $186 \mathrm{pg} / \mathrm{mL})$ 간에 유의한 차이가 없었다 $(p>0.05)$ (Fig. 2).
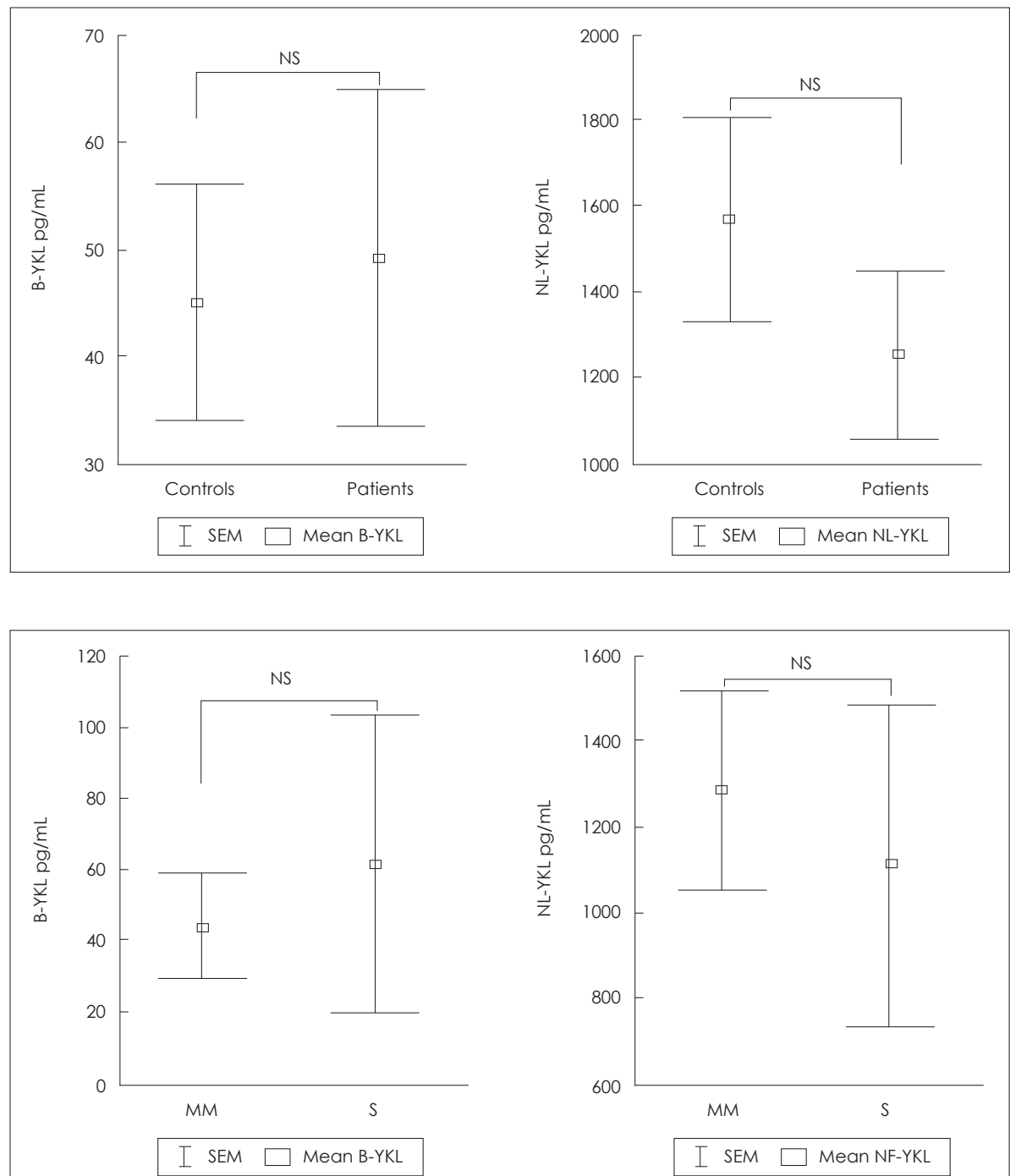

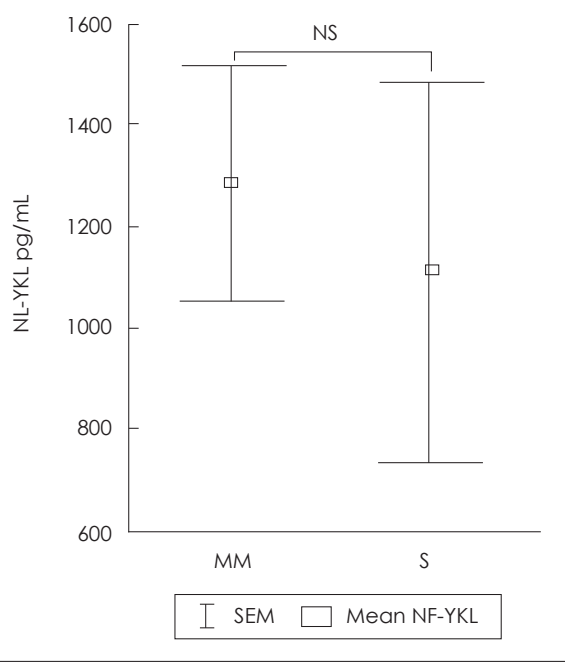

Fig. 1. Levels of blood YKL-40 (B-Y$\mathrm{KL}$ ) and nasal lavage fluid $\mathrm{YKL}-40$ (NL-YKL) in allergic rhinitis patients and controls. The level of YKL-40 was not significantly increased in allergic rhinitis patients compared to controls. Data expressed as means \pm SEM. NS: not significant, SEM: standard error of mean.
Fig. 2. Levels of blood YKL-40 (B-Y$\mathrm{KL}$ ) and nasal lavage fluid $\mathrm{YKL}-40$ (NL-YKL) of groups with mild-moderate symptom (MM) and severe symptom (S) in allergic rhinitis patients by symptom score. The level of YKL-40 was not significantly different in both groups. Data expressed as means \pm SEM. NS: not significant, SEM: standard error of mean. 
Fig. 3. Levels of blood YKL-40 (B-Y$\mathrm{KL}$ ) and nasal lavage fluid YKL-40 (NL-YKL) of groups with mild symptom (M) and moderate-severe symptom (MS) in allergic rhinitis patients by ARIA classification. The level of YKL-40 was not significantly different in both groups. Data expressed as means \pm SEM. NS: not significant, ARIA: allergic rhinitis and its impact on asthma, SEM: standard error of mean.

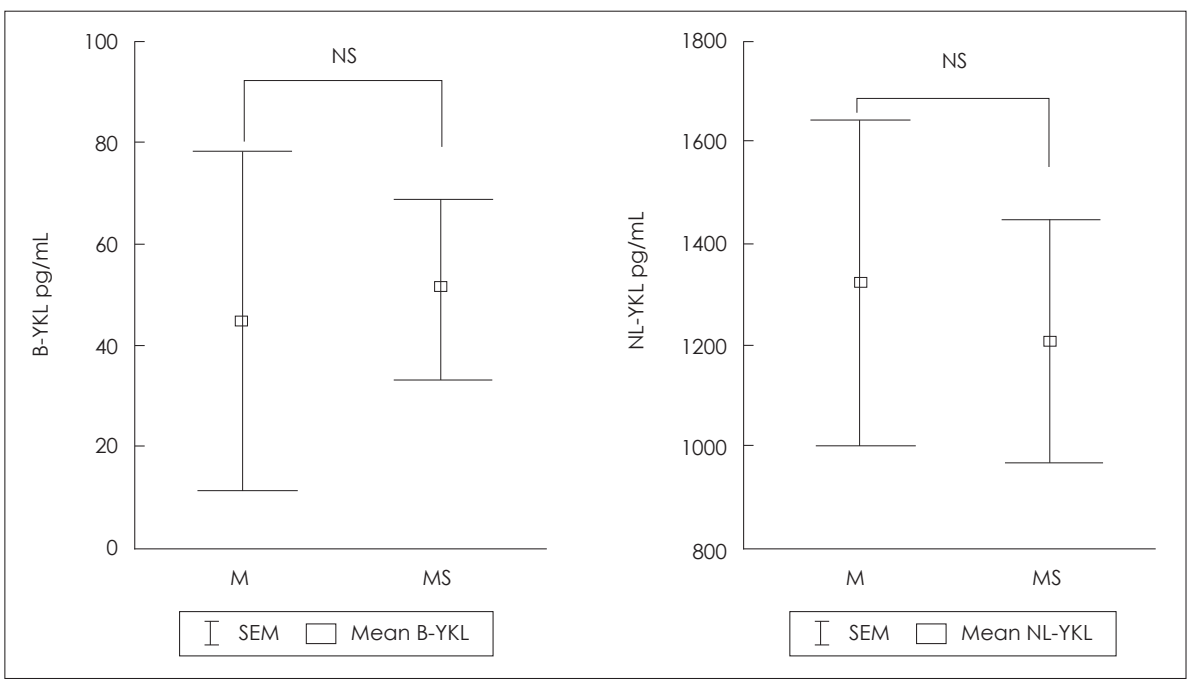

알레르기비염의 3대 증상(코막힘, 콧물, 재채기)의 각각 점 수와 B-YKL, 그리고 NL-YKL 수준과의 유의한 상관관계는 보이지 않았다 $(p>0.05)$.

\section{ARIA 분류에서 증상에 따른 경증군(intermittent and persistent mild group)과 중등-중증군(intermittent and persistent moderate-severe group)의 B-YKL과 $\mathrm{NL}-\mathrm{YKL}$ 의 비교}

ARIA 분류에 의해 경증-중등군은 18 명, 중증군은 44 명이 었다. 혈청 총 $\mathrm{IgE}$ 의 비교에서 중등-중증군 $(524 \pm 113 \mathrm{U} / \mathrm{mL})$ 과 경증군 $(524 \pm 101 \mathrm{U} / \mathrm{mL})$ 간에 유의한 차이가 보이지 않았 다 $(p>0.05)$. 혈중 호산구 수의 비교에서 중등-중증군 $(0.26 \pm$ $0.03 / \mu \mathrm{L})$ 과 경증 $(0.26 \pm 0.05 / \mu \mathrm{L})$ 간에 유의한 차이는 보이지 않 았다 $(p>0.05)$.

$\mathrm{B}-\mathrm{YKL}$ 수준은 경증군 $(44 \pm 16 \mathrm{pg} / \mathrm{mL})$ 과 중등-중증군 $(50 \pm$ $8 \mathrm{pg} / \mathrm{mL}$ ) 간에 유의한 차이가 없었다( $p>0.05$ )(Fig. 3). NL-

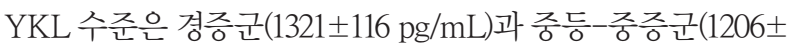
$121 \mathrm{pg} / \mathrm{mL}$ ) 간에 유의한 차이가 없었다( $p>0.05)$ (Fig. 3).

\section{고 찰}

알레르기비염과 천식은 면역학적으로 호산구, $\mathrm{T}$ 세포, 비반 세포의 침윤과 그에 따른 매개물, chemokine, cytokine과 국 소, 전신적 면역글로불린 $\mathrm{E}$ 생성으로 인한 유사한 염증 반응을 보이며, 역학적 임상적 증거 자료로 하나의 기도에 발생하는 하나의 질환이라고 인식되고 있다. ${ }^{13)}$

인간에서 밝혀진 chitinase 유사 단백질(chitinase-like proteins)로 acidic mammalian chitinase (CHIA), chitotriosidase (CHIT1), oviduction, YKL-40(CHI3L1) 그리고 YKL-39가 알
려져 있다.,9) 천식과 YKL-40과의 연관성을 보면 총 253 명의 천식환자를 대상으로 시행되었는데 환자군의 혈청 $\mathrm{YKL}-40$ 수준과 대조군의 혈청 YKL-40 수준을 비교한 결과 천식환 자군에서 유의하게 증가된 소견을 보였다. ${ }^{11)}$ 혈청 YKL-40 수 준이 기관폐포세척액 YKL-40 수준에 비례하고, 천식의 심한 정도에 따라 증가되었다. 이러한 점에 주목하여 YKL-40 수준 과 천식의 심한 정도에 상관성이 있다는 점이 강조되었다. 증가 된 YKL-40 수준이 천식환자의 기관지 상피하 기저막의 두께 와 양적인 상관성이 있다는 병리소견을 통해 천식에서의 만성 기도 폐쇄의 의미 있는 표지자로 사용될 수 있음을 시사하였 다. 치료적인 측면에서 YKL-40 수준이 증가되면 천식환자가 현재 천식 치료에 잘 반응하지 않음을 반영할 수 있으며, 심한 천식치료에서 YKL-40이 치료대상의 표적으로 고려될 수 있음 이 보고되었다. ${ }^{14}$ 이러한 연구를 바탕으로 YKL-40을 암호화 하는 chitinase 3-like 1(CHI3L1) 유전자에 대한 다형성 연구 가 진행되었는데 천식에 대한 증가된 감수성, 기관지 과민성, 그 리고 감소된 폐 기능에 연관성이 있다고 보고되었다. ${ }^{15)}$ 혈청 YKL-40의 증가는 CHI3L1 유전자의 CC형에서 연관성이 있 었고, $\mathrm{CG}$ 와 $\mathrm{GG}$ 형은 중등도 혹은 낮은 $\mathrm{YKL}-40$ 수준과 중등 도 혹은 낮은 천식 발병률을 보였다. 그러나 최근 chitinase 유 사 단백질을 암호화하는 CHIA, CHITI, 그리고 CHI3L1 유전 자에 대한 다형성 연구에서 천식과 연관성이 전혀 없었다고 보 고 되어 그 전 연구 ${ }^{15}$ 와는 상반된 결과를 보였다. ${ }^{16}$

금번 연구는 연구 대상을 대조군과 알레르기비염군으로 분 류하여 혈청 및 비세척액에서 YKL-40 수준을 비교함은 물론 이고 설문지를 통한 알레르기비염 3대 증상을 근거로 한 증상 점수에 따라 알레르기비염군을 경증-중등군(1 6점)과 중증 군(7 9점)의 두 군으로 나누었다. 그리고 ARIA 분류에 근거하 여 증상의 심함에 따라 즉, 경증 간헐성군과 경증 지속성군을 
경증군으로, 중등-중증 간헐성군과 중등-중증 지속성군을 중 등-중증군으로 나누어 연구하게 되었다. 선행된 외국 연구 ${ }^{11)}$ 에 서 YKL-40이 천식의 심한 정도에 상관성이 있다는 점에 근거 하여 알레르기비염에서도 증상 정도에 따라 표현형을 구분하 게 되었다. 그러나 대조군과 알레르기비염군에서 뿐만 아니라 알레르기비염의 증상 정도에 따른 YKL-40 수준의 비교에서도 차이를 보이지 않았다. 알레르기비염의 3대 증상(코막힘, 콧물, 재채기)의 각각 점수에 대한 혈액과 비세척액의 YKL-40 수 준과 유의한 상관관계가 없었다. 이 연구결과를 통해 YKL-40 이 알레르기비염 염증반응에 중요한 역할을 담당하지는 않는 것으로 판단된다. 최근 알레르기비염 환자를 대상으로 한 $\mathrm{YKL}^{-}$ 40의 연구가 보고되었다. ${ }^{17)}$ 알레르기비염 환자군와 대조군을 대상으로 시행되었는데 환자군의 혈청 $\mathrm{YKL}-40$ 수준과 대조 군의 혈청 YKL-40 수준을 비교한 결과 알레르기비염 환자군 에서 유의하게 증가된 소견을 보였다 $(p=0.09)$. 또한, 혈청 $\mathrm{YKL}^{-}$ 40 수준이 알레르기비염의 심한 정도에 양적인 상관관계를 보 였고, 알레르기비염의 코막힘, 맑은 콧물, 재채기, 코 가려움의 증상들 중에서 특히 코막힘, 코 가려움에 대해 양적인 상관성 을 보고하였다. 그러나 코막힘, 코 가려움에 대해 양적인 상관 성을 보였는지에 대한 기전이나 추가적인 설명은 언급되지 않 았다. 이처럼 기존의 연구와 금번 연구의 차이는 몇 가지 이유 로 설명될 수 있을 것이다. 첫째, 알레르기 검사법의 차이이다. Kwon 등 ${ }^{17)}$ 의 연구는 알레르기검사법으로 피부단자검사를 시 행한 반면, 금번 연구는 MAST를 시행하였는데 서로간에 알 레르기 항원의 양성률에 차이를 보일 수 있다. 최근 Jang 등 ${ }^{18)}$ 에 의하면 Allergy Screen을 이용한 MAST와 피부단자검사를 비교한 결과 피부단자검사를 기준으로 하여 시약별 일치율과 민감도 및 특이도를 살펴보았는데 일치율이 72.7 98.3\%, 민감 도는 33.3 96.5\%, 특이도는 73.5 98.9\%였다. MAST는 피부단 자검사와 높은 일치율과 특이도를 보인 반면, 비교적 낮은 민 감도를 보였다고 보고하였다. 둘째, Kwon 등근 51 명의 알레르 기비염 환자와 9 명의 대조군을 대상으로 한 반면, 본 연구는 62 명의 알레르기비염 환자와 대조군 36 명을 대상으로 하여 보다 충분한 대조군을 확보하여 연구를 진행하였다. 셋째, Kwon 등ㄱ) 은 연구 샘플을 혈청으로 국한하여 진행하였고 본 연구는 혈청 뿐만 아니라 비세척액을 얻어 동시에 수행하였다. 넷째, 환자의 증상 점수를 알레르기비염의 3대 증상뿐만 아니라 추가적으 로 ARIA 분류에 근거하여 현재 연구를 시행하였다.

지금까지 $\mathrm{YKL}-40$ 과 알레르기비염과의 연관성에 대한 연 구는 거의 미미한 상태로 Kwon 등기의 연구와 상반된 결과를 보였고 금번 연구결과만으로 $\mathrm{YKL}-40$ 이 알레르기비염과의 연관성이 적거나 없다고 단정하기는 매우 어려울 것 같다. 앞 으로 YKL-40의 알레르기비염에 대한 연구들이 추가적으로
필요할 것으로 생각된다.

\section{Acknowledgments}

This work was supported by a grant from the Korea Health 21 R\& D Project by the Ministry of Health and Welfare (A010251).

\section{REFERENCES}

1) Frieri M. Inflammatory issues in allergic rhinitis and asthma. Allergy Asthma Proc 2005;26(3):163-9.

2) Chang MK, Kim SW, Cho JS, Cha CI. The relation between early allergic response and nasobronchial relationship and the associated factors of bronchial hyperreactivity in allergic rhinitis patients. Korean J Otolaryngol-Head Neck Surg 2006;49(8):795-801.

3) Araujo AC, Souto-Padrón T, de Souza W. Cytochemical localization of carbohydrate residues in microfilariae of Wuchereria bancrofti and Brugia malayi. J Histochem Cytochem 1993;41(4):571-8.

4) Boot RG, Blommaart EF, Swart E, Ghauharali-van der Vlugt K, Bijl $\mathrm{N}$, Moe $\mathrm{C}$, et al. Identification of a novel acidic mammalian chitinase distinct from chitotriosidase. J Biol Chem 2001;276(9):6770-8.

5) Boot RG, Renkema GH, Verhoek M, Strijland A, Bliek J, de Meulemeester TM, et al. The human chitotriosidase gene. Nature of inherited enzyme deficiency. J Biol Chem 1998;273(40):25680-5.

6) Shibata Y, Honda I, Justice JP, Van Scott MR, Nakamura RM, Myrvik $\mathrm{QN}$. Th1 adjuvant $\mathrm{N}$-acetyl-D-glucosamine polymer up-regulates Th1 immunity but down-regulates Th2 immunity against a mycobacterial protein (MPB-59) in interleukin-10-knockout and wildtype mice. Infect Immun 2001;69(10):6123-30.

7) Strong P, Clark H, Reid K. Intranasal application of chitin microparticles down-regulates symptoms of allergic hypersensitivity to Dermatophagoides pteronyssinus and Aspergillus fumigatus in murine models of allergy. Clin Exp Allergy 2002;32(12):1794-800.

8) Bleau G, Massicotte F, Merlen Y, Boisvert C. Mammalian chitinaselike proteins. EXS 1999;87:211-21.

9) Sun YJ, Chang NC, Hung SI, Chang AC, Chou CC, Hsiao CD. The crystal structure of a novel mammalian lectin, Ym1, suggests a saccharide binding site. J Biol Chem 2001;276(20):17507-14.

10) Zhu Z, Zheng T, Homer RJ, Kim YK, Chen NY, Cohn L, et al. Acidic mammalian chitinase in asthmatic Th2 inflammation and IL-13 pathway activation. Science 2004;304(5677):1678-82.

11) Chupp GL, Lee CG, Jarjour N, Shim YM, Holm CT, He S, et al. A chitinase-like protein in the lung and circulation of patients with severe asthma. N Engl J Med 2007;357(20):2016-27.

12) Okuda M, Sakaguchi K, Ohtsuka $H$. Intranasal beclomethasone: mode of action in nasal allergy. Ann Allergy 1983;50(2):116-20.

13) Bousquet J, Van Cauwenberge P, Khaltaev N; Aria Workshop Group; World Health Organization. Allergic rhinitis and its impact on asthma. J Allergy Clin Immunol 2001;108(5 Suppl):S147-334.

14) Sutherland TE, Maizels RM, Allen JE. Chitinases and chitinase-like proteins: potential therapeutic targets for the treatment of T-helper type 2 allergies. Clin Exp Allergy 2009;39(7):943-55.

15) Ober C, Tan Z, Sun Y, Possick JD, Pan L, Nicolae R, et al. Effect of variation in CHI3L1 on serum YKL-40 level, risk of asthma, and lung function. N Engl J Med 2008;358(16):1682-91.

16) Wu AC, Lasky-Su J, Rogers CA, Klanderman BJ, Litonjua A. Polymorphisms of chitinases are not associated with asthma. J Allergy Clin Immunol 2010;125(3):754-7, 757.e1-757.e2.

17) Kwon JW, Kim TW, Cho SH, Min KU, Park HW. Serum YKL-40 levels are correlated with symptom severity in patients with allergic rhinitis. Allergy 2011;66(9):1252-3.

18) Jang WR, Nahm CH, Kim JH, Lim DH, Jang TY, Moon YS, et al. [Allergen specific IgE measurement with Polycheck Allergy: comparison of three multiple allergen simultaneous tests]. Korean J Lab Med 2009;29(5):465-72. 